\title{
KAJIAN BENTUK RAGAM HIAS PADA MIMBAR SUNAN PRAPEN
}

\author{
Rizal Wahyu Bagas Pradana \\ Institut Seni Indonesia Surakarta \\ ryzalwbp@gmail.com
}

\begin{abstract}
Abstrak
Mimbar Sunan Prapen merupakan salah satu mimbar kuno yang dibuat pada zaman Walisongo, yaitu pada masa Sunan Prapen. Keindahan mimbar Sunan Prapen, tidak terlepas dari keberadaan ragam hias pada setiap bagiannya. mimbar. Penelitian ini bertujuan untuk menjelaskan bentuk ragam hias di mimbar Sunan Prapen. Kajian ini menggunakan metode penelitian kualitatif, dengan interpretasi analisis melalui pendekatan estetika. Hasil penelitian menunjukkan bentuk ragam hias di mimbar Sunan Prapen dipengaruhi oleh budaya pra Islam (Hindu-Budha) dan Islam. Ragam hias di mimbar Sunan Prapen dapat dikelompokan ke dalam beberapa motif seperti motif lung-lungan, sulur, padma, sorotan, hiranyagarba, dan kala. Bentuk ragam hias di mimbar Sunan Prapen melanjutkan gaya seni hias pra Islam, dengan beberapa pengubahan atau pengembangan bentuk. Pengubahan tersebut mengacu pada pedoman dalam Agama Islam yang tidak diperbolehkan menampilkan penggambaran makhluk hidup.
\end{abstract}

Kata Kunci: bentuk, ragam hias, mimbar Sunan Prapen

\begin{abstract}
The Sunan Prapen pulpit is one of the ancient pulpits made during the Walisongo era, namely the Sunan Prapen period. The beauty of the Sunan Prapen pulpit is inseparable from the presence of ornaments in every part. pulpit. This study aims to explain the shape of the ornament on the Sunan Prapen pulpit. This study uses qualitative research methods, with analysis interpretation through an aesthetic approach. The results showed that the decorative forms on the Sunan Prapen pulpit were influenced by pre-Islamic (Hindu-Buddhist) and Islamic culture. The ornaments on the Sunan Prapen pulpit can be grouped into several motifs such as lung-lungan, sulur, padma,sorotant, hiranyagarba, and kala motifs. The decorative forms on the Sunan Prapen pulpit continue the pre-Islamic decorative art style, with several changes or development of forms. The amendment refers to the guidelines in Islam which are not allowed to depict living things.
\end{abstract}

Keywords: form, ornament, Sunan Prapen pulpit

\section{PENDAHULUAN}

Ragam hias dirancang untuk menambah nilai estetis atau keindahan pada suatu benda. Terdapat beberapa istilah yang berkaitan dengan ragam hias antara lain ornamen (ornament), seni dekoratif (decorative art), dan seni hias. Meskipun memiliki perbedaan istilah, akan tetapi semuanya merujuk kepada sebuah pemahaman yang hampir sama. Seni ragam hias telah dipakai oleh manusia dalam berbagai macam periode dan peradaban. Perkembangan ragam hias di Nusantara telah dikenal lama bahkan sebelum agama Islam datang. Pada masa pra Islam, ragam hias banyak menghiasi tempat ataupun barang yang berkaitan dengan peribadatan. Kemudian setelah Islam masuk di Nusantara, terjadilah perubahan gaya yang berbeda dengan masa sebelumnya. Perubahan yang signifikan terlihat pada perubahan bentuk penggambaran ragam hias makhluk hidup khususnya manusia dan hewan. Pengubahan yang 
dilakukan tersebut melalui stilasi dan deformasi. Ambary menyatakan, bahwa munculnya penggambaran mahluk hidup dengan cara disamarkan didasarkan atas konsepsi yang bersifat agamawi (Islam) (Ambary, 1998, p. 113). Pengubahan ini merupakan salah satu bentuk kebijaksanaan yang dirintis para Waliyullah dalam menyebarkan agama Islam di Nusantara, tanpa danya kekerasan, dengan pendekatan budaya. Dalam bidang seni ragam hias, kebijaksanaan tersebut melahirkan motifmotif hias yang sebenarnya merupakan motifmotif hias Indonesia-Hindu, hanya saja polapola hias pra Islam yang banyak menekankan visualisasi makhluk hidup, diganti dengan visualisasi abstrak dan simbolis berupa unsurunsur ornamen yang selalu menghindari visualisasi makhluk hidup (Rahym, 1983, p. 11). Salah satu bentuk akulturasi budaya dalam ragam hias, antara gaya pra Islam dan Islam terlihat pada mimbar Sunan Prapen.

Sunan Prapen adalah anak dari Sunan Dalem, dan cucu Sunan Giri. Sunan Giri mendirikan kerajaan bernama Giri Kedaton. Sunan Prapen, adalah pemimpin agama Islam ke empat, setelah menggantikan kepemimpinan adiknya, Pangeran Seda-ing Margi, yang meninggal dalam perjalanan (Tjahjono, 2004, p. 19). Pada masa pemerintahan Sunan Prapen, Giri Kedaton mencapai puncak kejayaannya. Keunikan bentuk ragam hias di mimbar Sunan Prapen tidak dapat terlepas dari lingkungan masyarakat Giri sebagai tempat terciptanya karya seni tersebut, yang di dalamnya tercermin unsur kearifan lokal dan budaya dari masyarakat Giri. Keberadaan ragam hias di mimbar Sunan Prapen memiliki gaya yang sama dengan ragam hias yang terdapat di Masjid Ainul Yaqin Sunan Giri. Kesamaan tersebut terjadi karena mimbar Sunan Prapen dan Masjid Sunan Giri berada di wilayah sama yaitu di Desa Giri, serta dibuat pada waktu yang masih sezaman. Penelitian tentang ragam hias Masjid Sunan Giri pernah dilakukan penulis tahun (Pradana, 2019), Masjid Ainul Yaqin Sunan Giri: Tinjauan Seni Bangunan, Ragam Hias, dan Makna Simbolik. Ragam Hias di Masjid Sunan Giri menggambil dan mengolah unsur-unsur pra Islam sebagai motifnya, dengan beberapa perubahan/ pengembangan, menyesuaikan dengan aturan yang terdapat dalam Agama Islam (Pradana, 2020, p. 83). Bentuk ragam hias bergantung pada kebudayaan masyarakat tersebut, seperti ragam hias di mimbar Sunan Prapen. Tentunya berbeda pula dengan ragam hias di luar wilayah kebudayaan masyarakat Giri atau wilayah kekuasaan Kerajaan Giri Kedaton. Mimbar selalu menjadi bagian dari arsitektur masjid, hal ini berkaitan dengan fungsi mimbar itu sendiri. Seperti penelitian yang dilakukan Jeksi Dorno dalam Bentuk dan Makna Ornamen Ukir pada Interior Masjid Gedhe Yogyakarta (Dorno, 2014). Dalam penelitian tersebut mimbar Masjid Gedhe Yogyakarta memiliki karakteristik yang berbeda. Mimbar di Masjid Gedhe Yogyakarta dihiasi ragam hias yang menawan, menandakan kebesaran dari kesultanan Yogyakarta. Pada mimbar lain pada masjid-masjid kuno di Jawa, memiliki perbedaan gaya ragam hias. Bentuk dan gaya ragam hias kerajaan Demak, memiliki kesamaan dengan gaya kerajaan Giri Kedaton, akan tetapi berbeda dengan gaya periode setelahnya. Titis Hana Sasti dalam Mihrab dan Mimbar Masjid Jawa Tengah Abad 16-19 dalam Kajian Ikonografi (Sasti, 2014). Dalam penelitiannya dapat diketahui bahwa kebudayaan Hindu-Budha dan Cina turut memberikan pengaruh dalam bentuk ragam hias pada bangunan mimbar. Nampaknya hal ini dapat ditemukan pada ragam hias di mimbar Sunan Prapen. Karakter dan klasifikasi suatu bentuk bangunan mencirikan cipta, karsa dan karya sesuai dengan peradabannya, walau mungkin kecenderungan untuk berubah selalu ada (Alamsyah, 2010, p. 172).

Kajian tentang ragam hias pada bangunan mimbar umumnya merupakan suatu bagian yang tidak terpisahkan dari pengkajian terhadap bangunan masjid. Mimbar selalu menjadi bagian dari arsitektur masjid, hal ini berkaitan dengan fungsi mimbar itu sendiri. Penelitian yang secara khusus mengkaji ragam hias pada bangunan mimbar secara khusus jarang dilakukan. Umumnya menjadi sebuah kesatuan dari kajian arsitektur bangunan masjid. Ketika mimbar dilihat sebagai salah satu bagian masjid, kajian menjadi kurang tajam dan lebih bersifat umum. Keberadaan mimbar menjadi penting karena fungsinya, sebagai tempat singgasana 
ulama menyiarkan khotbah atau dakwah. Mimbar Sunan Prapen pada awalnya dipakai sebagai singgasana ketika berkhotbah jumat atau berdakwah di masjid Giri oleh Sunan Prapen. Sehingga tidak mengherankan apabila mimbar tersebut dihias seindah mungkin, mengingat kedudukan tinggi dari Sunan Prapen sebagai seorang raja, sekaligus ulama. Penempelan ragam hias oleh para ulama pada saat itu sebagai eksistensi manusia yang berkehendak untuk menciptakan keindahan pada benda-benda yang dipakainya dan khususnya bangunan masjid sebagai tempat ibadah (Anggarini, 2009, p. 209). Keberadaan motif pra Islam pada mimbar merepresentasikan toleransi umat Islam dengan kebudayaan yang telah ada sebelumnya.

Kajian tentang bentuk ragam hias di mimbar Sunan Prapen sangat menarik untuk diteliti. Tidak banyak mimbar pada zaman Walisongo yang dihias dengan ragam hias sedemikian rupa, sehingga adanya ragam hias pada mimbar tersebut menjadi daya tarik tersendiri, yang membedakan dengan mimbar lain pada umumnya. Sehubungan dengan hal tersebut, penelitian ini bertujuan untuk menjelaskan bentuk ragam hias yang terdapat di mimbar Sunan Prapen. Hasil dari penelitian ini diharapkan dapat memberikan sumbangan pengetahuan berkaitan dengan kajian bentuk ragam hias di mimbar Sunan Prapen serta kajian terhadap bentuk ragam hias pada masa penyebaran agama Islam di Jawa.

\section{METODE}

Penelitian ini menggunakan metode penelitian kualitatif yang diuraikan secara deskriptif. Penelitian kualitatif deskriptif menghasilkan data yang berupa kata-kata, gambar dan bukan angka, selain itu data yang dikumpulkan dapat menjadi kunci terhadap apa yang telah diteliti (Moleong, 2017, p. 11). Dengan demikian data yang telah dihimpun dalam penelitian ini berupa deskripsi katakata dan gambar. Pemilihan metode penelitian kualitatif deskriptif bertujuan untuk menjelaskan bentuk ragam hias di mimbar Sunan Prapen. Data penelitian diperoleh melalui observasi, wawancara, dokumentasi, dan studi pustaka. Sedangkan analisis data dalam penelitian ini melalui reduksi data, penyajian data, dan penarikan kesimpulan. Untuk mendapatkan data yang valid dilakukan triangulasi data dan informan review. Interpretasi data dalam penelitian ini menggunakan interpretasi data estetika. Estetika adalah ilmu yang mempelajari segala sesuatu yang berkaitan dengan keindahan, mempelajari semua aspek dari apa yang kita sebut keindahan (Djelantik, 2004, p. 7). Penelitian ini dilaksanakan pada bulan april 2019 di Masjid Besar Ainul Yaqin Sunan Giri yang terletak bersebelahan dengan kawasan makam Sunan Giri. Masjid Sunan Giri beralamat di Jl. Sunan Giri XVIII, Desa Giri, Kecamatan Kebomas, Kabupaten Gresik, Provinsi Jawa Timur.

\section{HASIL DAN PEMBAHASAN \\ Bentuk Ragam Hias Mimbar Sunan Prapen}

Mimbar Sunan Prapen dibuat tahun 1515 M yang awalnya digunakan sebagai tempat menyampaikan khotbah pada hari jumat oleh beliau dan masih digunakan hingga sekarang. Mimbar ini terbuat dari kayu jati, memiliki ukuran $1,3 \mathrm{~m}$ x $80 \mathrm{~cm} \times 3,5 \mathrm{~m}$. Permukaan mimbar Sunan Prapen dicat dengan warna hijau tosca dan emas (prada). Dalam pembahasan ragam hias pada mimbar Sunan Prapen, peneliti melakukan pembagian terhadap beberapa bagian mimbar. Hal ini dilakukan agar dapat mengetahui secara detail, jenis dan bentuk dari masing-masing komponen ragam hias yang terdapat pada mimbar Sunan Prapen. Pembagian ragam hias pada setiap bagian mimbar Sunan Prapen sebagai berikut:

a. Dasar Mimbar

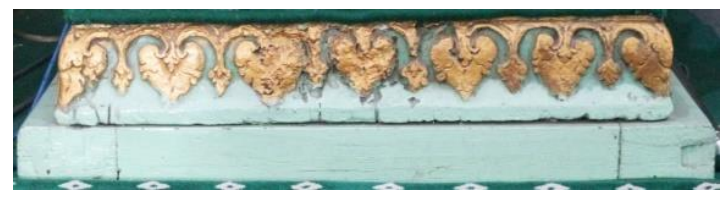

Gambar 1. Dasar Mimbar

(Sumber: Dokumen Penulis, 2019)

Ragam hias patran pada mimbar Sunan Prapen terdapat di dua tempat yaitu bagian dasar mimbar dan bagian sandaran mimbar. Bentuk ragam hias patran pada dasar 
mimbar tidak detail dibandingkan dengan yang berada di sandaran mimbar, karena ragam hias tersebut sudah rusak/aus.

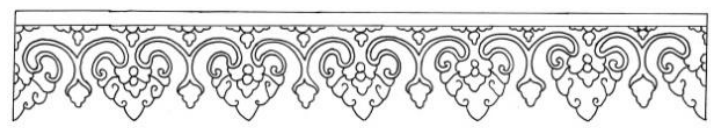

Gambar 2. Motif Patran

(Sumber: Dokumen Penulis, 2019)

b. Tempat Duduk (Sisi Depan Bawah dan Sandaran)

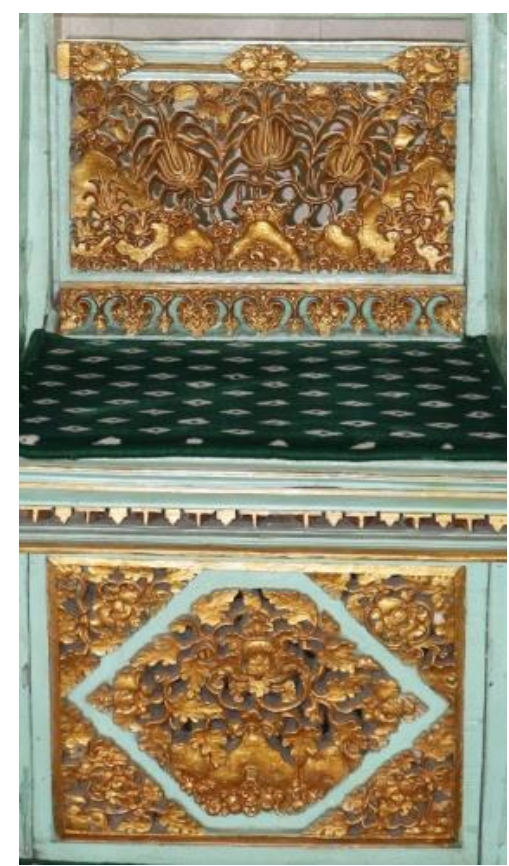

Gambar 3. Tempat Duduk Mimbar (Sumber: Dokumen Penulis, 2019)

Panel yang berada di bawah tempat duduk mimbar disusun dengan menggabungkan dua jenis ragam hias yaitu motif hiranyagarbha dan motif lung-lungan. Motif hiranyagarba berada di bagian tengah, dan menjadi pusat perhatian (point of interest) dari ragam hias di dalam panel tersebut. Sedangkan motif lung-lungan, mengisi bidang-bidang yang kosong, dan menjadi sebuah bingkai dari motif hiranyagarba. Penyusununan dari motif hiranyagarba diawali dengan penggambaran bentuk tanah yang telah distilasikan pada bagian paling bawah. Penggambaran tanah ini digunakan sebagai tempat pijakan dari batu cadas di atasnya. Sedangkan penggambaran batu cadas tersebut ditampilkan berjumlah tiga buah batu cadas, yang disusun secara berdampingan, dengan batu cadas bagian tengah yang memiliki ukuran terbesar. Dengan demikian dapat diketahui bahwa penggambaran batu cadas tersebut menunjukan sebuah ekosistem dari perbukitan atau pegunungan. Hal ini berdasarkan pada ekosistem batu cadas sebagai elemen penyusun ragam hias hiranyagarba yang banyak ditemui di daerah dataran tinggi dan jumlah batu cadas yang lebih dari satu buah, menunjukan sebuah penggambaran dari ekostitem perbukitan atau pegunungan. Pada ujung batu cadas bagian tengah, terdapat penggambaran sebuah bonggol yang telah distilasikan. Bonggol ini merupakan titik pangkal keluarnya ragam hias, berupa penggambaran stilasi tumbuhan merambat yang masih muda. Tumbuhan tersebut terdiri dari tiga bagian yaitu tangkai, daun, dan bunga. Pola penyusunan tumbuhan ini menyerupai motif sulur gelung yang sering digunakan sebagai penghias pelipit candi Hindu-Budha. Penggambaran tanah, batu cadas, dan tumbuhan tersebut disusun sedemikian rupa, hingga memenuhi seluruh bidang berbentuk seperti belah ketupat tanpa sebuah bingkai di sisi luarnya.

Pada bagian luar motif hiranyagarba terdapat penggambaran stilasi dari tumbuhan yang masih muda atau seringkali dinamakan sebagai motif lung-lungan. Secara umum ragam hias motif hiranyagarba dan motif lung-lungan memiliki kemiripan bentuk, akan tetapi yang menjadi faktor pembedanya adalah sebuah titik pangkal pada motif hiranyagarba, tidak terdapat pada motif lunglungan. Titik pangkal tersebut bisa berupa sebuah benda berupa guci, vas, atau tempayan yang berbentuk bulat (purnakalasa), ataupun berbentuk ramping (purnaghata) hingga berbentuk sebuah bonggol (padmamula) yang kerap kali digambarkan dengan tanah liat ataupun air sebagai tempat tumbuhnya. Motif lung-lungan tersebut diletakkan pada keempat sudut, di luar motif hiranyagarba, dan menempel dengan bingkai panel yang berbentuk persegi panjang. Bagian-bagian motif lung-lungan ini terdiri dari tangkai, daun, dan bunga yang disusun sedemikian rupa, hingga membentuk bidang segitiga tanpa sebuah bingkai di sisi luarnya. 


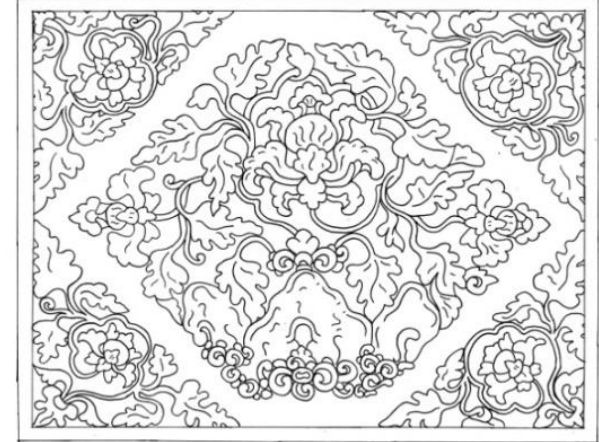

Gambar 4. Motif Hiranyagarba

(Sumber: Dokumen Penulis, 2019)

Pada bagian atas panel tersebut terdapat ragam hias bermotif geometris. Ragam hias ini menghiasi lis bagian depan tempat duduk mimbar. Motif geometris tersebut disusun secara horisontal dan saling berselingan. Pada masing-masing ujungnya diakhiri dengan motif geometris yang menyerupai bentuk tumpal dibelah dua.

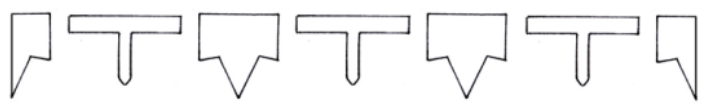

Gambar 5. Motif Geometris

(Sumber: Dokumen Penulis, 2019)

Ragam hias patran pada sandaran mimbar terletak di bagian paling bawah dari rangkaian ragam hias pada sandaran mimbar. Ragam hias tersebut berbentuk gabungan dari stilasi bunga, daun, dan garis yang diletakan secara berderet-deret. Bunga dalam ragam hias ini digambarkan terpotong setengah bagian dan terletak pada bagian paling atas. Di bawahnya terdapat daun dan lengkungan garis yang membentuk cungkup di ujungnya.

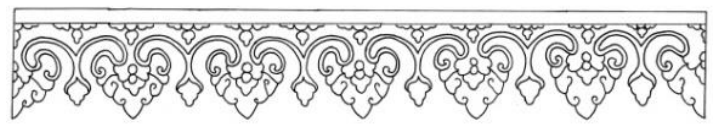

Gambar 6. Motif Patran

(Sumber: Dokumen Penulis, 2019)

Sandaran mimbar Masjid Ainul Yaqin Sunan Giri, dihiasi dengan beberapa ragam hias yang berada di dalam maupun di luar panel. Di dalam panel terdapat penggambaran ragam hias bermotif hiranyagarba. Motif tersebut terdapat dalam bentuk penggambaran ketiga pohon kalpataru, maupun kedua tanaman yang merambat. Ketiga pohon kalpataru dalam panel ini digambarkan masih muda, dan memiliki ukuran yang berbedabeda. Satu pohon berukuran lebih besar dan dijadikan sebagai fokus utama (point of interest). Sedangkan kedua pohon kalpataru lainnya berukuran lebih kecil, terletak di sisi kiri dan sisi kanan dari pohon kalpataru yang berukuran besar. Pohon kalpataru yang berukuran besar tersebut berada di bagian tenggah panel.

Pohon ini tumbuh dari sebuah vas atau tempayan yang pangkalnya tertutup oleh tanah liat dan batu cadas. Pohon kalpataru tersebut membentuk tiga buah percabangan. Setiap cabang dari pohon ini digambarkan sedang mengalami pertumbuhan. Hal ini dapat dilihat dari kemunculan bagian kuncup bunga pada kedua sisinya dan sebuah tunas di masing-masing puncak ketiga percabangan tersebut. Sedangkan bagian bawah dari tumbuhan ini terdapat lagi dua pohon kalpataru lainnya, yaitu di sisi kiri dan kanan, akan tetapi dengan ukuran yang lebih kecil. Kedua pohon tersebut digambarkan tumbuh di atas tanah dan masing-masing berada di depan sebuah batu cadas. Berbeda dengan pohon kalpataru sebelumnya, kedua pangkal pohon kalpataru ini tidak berada di dalam sebuah vas atau tempayan. Di bagian bawah kedua pohon ini terlihat bonggol yang telah menyatu dengan tanah. Bonggol tersebut merupakan titik pangkal tumbuhnya kedua pohon kalpataru.

Selain pohon kalpataru, terdapat dua penggambaran tumbuhan merambat yang masih muda. Kedua tumbuhan tersebut masing-masing terdiri dari empat bagian yaitu bonggol, tangkai, daun, dan bunga. Bonggol terletak di bagian terbawah, dan terlihat tumbuh di atas batu cadas. Bonggol tersebut merupakan titik pangkal tumbuhnya tangkai, daun, dan bunga. Motif hiranyagarba ini disusun sedemikian rupa, hingga memenuhi seluruh bidang panel berbentuk persegi panjang tanpa sebuah bingkai di sisi luarnya. 


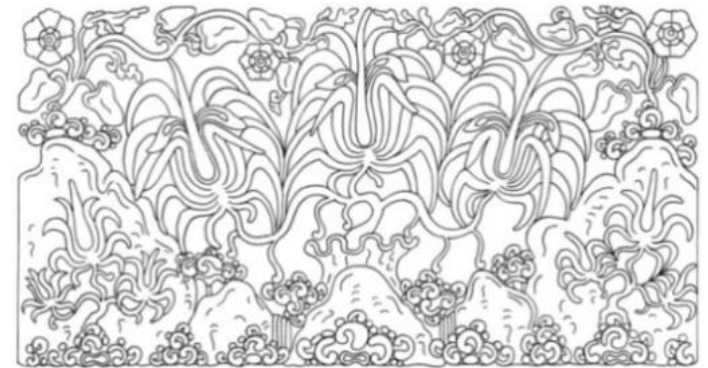

Gambar 7. Motif Hiranyagarba

(Sumber: Dokumen Penulis, 2019)

Kedua suluran ini berada pada bagian paling atas dari serangkaian hiasan di sandaran mimbar. Masing-masing pangkal suluran tersebut terdapat alas berbentuk bidang persegi panjang yang disusun secara vertikal. Kedua suluran ini masing-masing diletakkan di bagian ujung sisi kanan maupun sisi kiri, dan dihubungkan melalui sebuah bidang berbentuk garis memanjang secara horisontal.
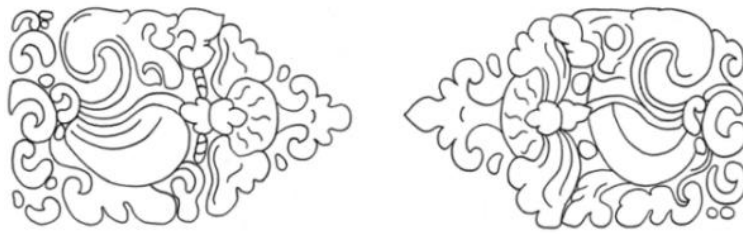

Gambar 8. Motif Sulur

(Sumber: Dokumen Penulis, 2019)

Pada bagian tengah garis tersebut, lebih tepatnya di antara kedua hiasan suluran ini terdapat sebuah ragam hias kala. Adanya bidang garis memanjang ini menjadi penghubung antara kedua suluran yang masing-masing berada pada bagian ujung, dengan ragam hias kala yang berada tepat pada bagian tengah. Motif kala tersebut digambarkan memiliki bentuk luar bidang belah ketupat. Sedangkan penggambaran motif kala tersebut tidak dilakukan seperti pada relief ataupun candi periode HinduBudha. Penggambaran tersebut dilakukan dengan cara pengubahan bentuk fisik kala sebagai makhluk hidup menjadi tumbuhtumbuhan. Hal ini terjadi karena penggambaran makhluk hidup secara naturalis, seperti pada periode Hindu-Budha tidak sesuai dengan ajaran agama Islam. Dengan demikian penggambaran motif kala tersebut terdiri atas motif sulur yang disusun sedemikian rupa, hingga membentuk karakter kala. Penggambaran bentuk motif kala dengan cara seperti ini merupakan hal yang umum, sebagai bentuk akulturasi budaya HinduBudha dan Islam.

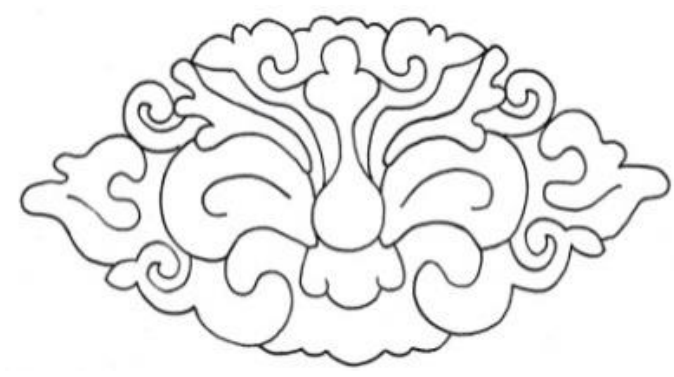

Gambar 9. Motif Kala

(Sumber: Dokumen Penulis, 2019)

\section{c. Tiang Mimbar}

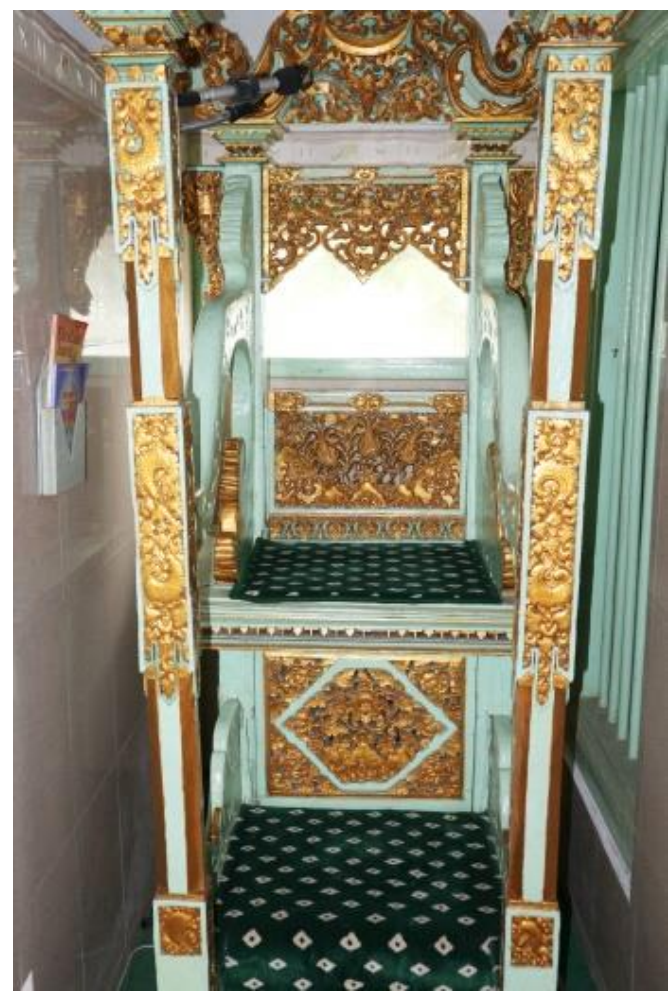

Gambar 10. Tiang Mimbar

(Sumber: Dokumen Penulis, 2019)

Pada kedua tiang penyangga bagian depan mimbar dihiasi dengan ragam hias bermotif sulur. Motif suluran tersebut berada di bagian paling bawah dari serangkain ragam hias pada tiang mimbar. Hiasan sulur-suluran 
tersebut mengisi sebuah bidang datar berbentuk persegi panjang ke bawah. Suluran pada tiang ini bergaya majapahit, gaya tersebut ditunjukkan melalui bentuk daun pokoknya yang ikal dan memiliki jambul di bagian mukanya.
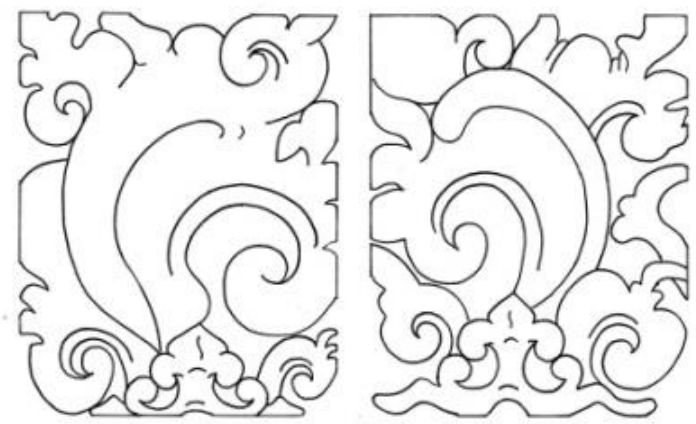

Gambar 11. Motif Sulur

(Sumber: Dokumen Penulis, 2019)

Pada tiang mimbar Masjid Ainul Yaqin Sunan Giri terdapat dua bentuk penggambaran ragam hias motif sorotan, yang masing-masing memiliki perbedaan dari segi isen-isen dan ukurannya. Motif sorotan tersebut menghiasi setiap sisi dari kedua tiang mimbar bagian depan. Keunikan motif sorotan di tiang mimbar ini dapat dilihat pada bagian pangkalnya yang berbentuk tiga ujung runcing dari sebuah mata trisula. Sedangkan kedua sisi luar dari ujung motif sorotan ini membentuk cekungan di sisi luarnya, sehingga hanya bagian tengahnya saja yang terlihat sejajar dengan motif sorotan. Bagian tengah inilah yang terlihat seperti sebuah penghubung antara motif sorotan bagian bawah dan bagian atas.

Motif sorotan di bagian bawah memiliki ukuran yang lebih lebar dibandingkan motif sorotan di bagian atas. Motif sorotan di bagian bawah tersebut mengisi bagian tengah kedua tiang mimbar. Pada bagian dalam motif sorotan ini terdapat isen-isen berupa sulur-suluran yang masingmasing digambarkan saling berhadapan.
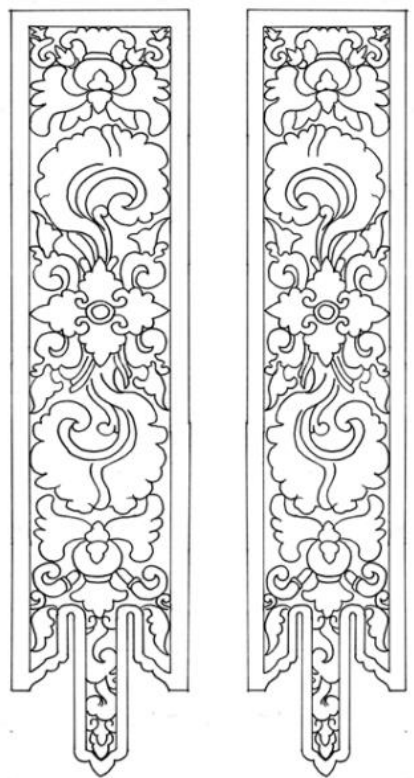

Gambar 12. Motif Sorotan

(Sumber: Dokumen Penulis, 2019)

Sedangkan motif sorotan bagian atas memiliki lebar yang lebih kecil dan menyatu dengan bagian ujung tiang mimbar. Sama seperti motif sorotan bagian bawah, di bagian dalamnya juga terdapat isen-isen berupa sulur-suluran yang masing-masing digambarkan secara saling berhadapan. Keberadaan motif sorotan dengan warna hijau tosca dan sulur-suluran sebagai isen-isen dengan warna emas, memberikan kesan kemewahan pada tiang mimbar.
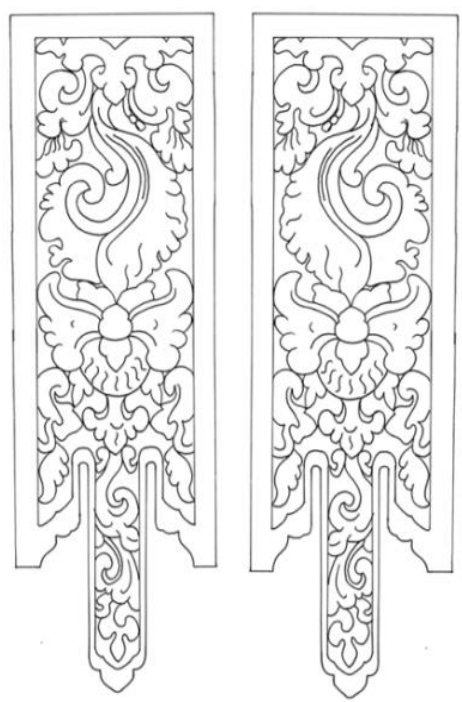

Gambar 13. Motif Sorotan (Sumber: Dokumen Penulis, 2019) 
Pada tiang mimbar Masjid Ainul Yaqin Sunan Giri terdapat ragam hias bermotif patran. Motif patran tersebut memiliki dua bentuk antara lain digambarkan secara utuh dan setengah bagian. Motif ini disusun secara horisontal, berderet-deret, dan melingkari tiang mimbar.
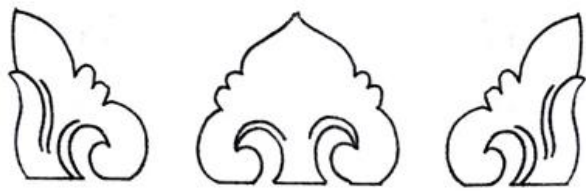

Gambar 14. Motif Patran

(Sumber: Dokumen Penulis, 2019)

Pada bagian teratas tiang mimbar terdapat ragam hias bermotif geometris. Motif geometris tersebut dibagi menjadi tiga bagian. Bagian pertama berada di tempat teratas tiang mimbar dan disusun secara berderet-deret. Bagian kedua dan ketiga terletak di bawah bagian pertama. Bagian kedua dan ketiga terbentuk karena adanya hiasan tiang mibar berupa gonjo mayangkoro yang berbentuk bunga teratai. Jika dilihat dari samping hiasan bunga teratai tersebut, membentuk serangkaian motif geometris.

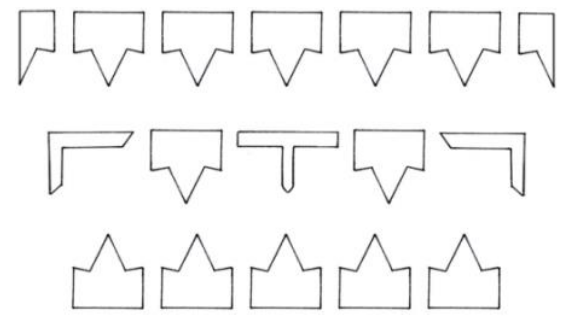

Gambar 15. Motif Geometris (Sumber: Dokumen Penulis, 2019)

\section{d. Busur Mimbar}

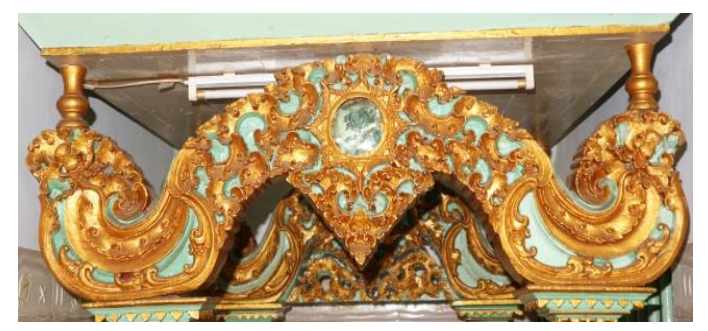

Gambar 16. Busur Mimbar (Sumber: Dokumen Penulis, 2019)
Telah diketahui bahwa bentuk kedua busur di bagian atas relung mimbar ini menyerupai hiasan kala makara. Kala makara adalah penggabungan dari motif kala di bagian puncaknya dan motif makara di bagian pangkalnya. Keberadaan motif ini biasa diletakkan di relung pintu masuk candi-candi Hindu-Budha. Mengingat penggambaran bentuk makhluk hidup yang tidak sesuai dengan ajaran agama Islam, maka penggunaan ragam hias kala makara sebagai penghias busur mimbar tidak digunakan. Ragam hias kala makara tersebut digantikan dengan hiasan bermotif sulur-suluran dan surya majapahit ataupun bulan sabit. Dengan demikian terjadilah sebuah proses akulturasi budaya antara Hindu-Budha dan Islam.

Pada busur mimbar bagian depan ragam hias bermotif kepala kala digantikan dengan motif surya majapahit. Sedangkan penggunaan motif sulur sebagai penghubung antara hiasan kala dan makara masih tetap digunakan. Akan tetapi telah terjadi perubahan bentuk motif sulur disesuaikan dengan gaya ragam hias yang berkembang di masa itu. Selain itu, penggambaran motif makara di bagian pangkal kedua busur tersebut, digantikan dengan hiasan berupa bunga yang sedang bermekaran. Hiasan bunga ini merupakan bagian ujung dari penggambaran sulur-suluran di busur mimbar.

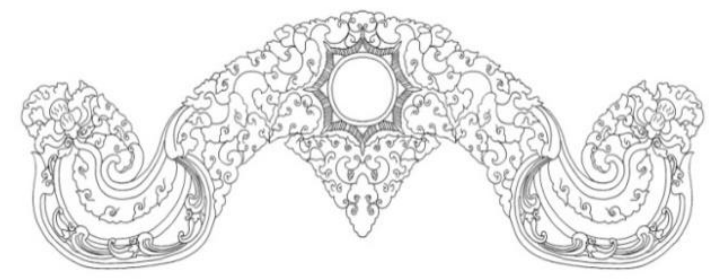

Gambar 17. Motif Sulur

(Sumber: Dokumen Penulis, 2019)

Secara umum pada busur mimbar bagian belakang memiliki bentuk yang hampir sama dengan busur mimbar bagian depan. Hanya saja yang membedakan, di busur bagian belakang terdapat penambahan motif sulur lain di bagian bawah busur. Suluran tersebut mengisi ruang kosong yang berada di bagian bawah busur. Selain itu pada bagian tengah busur ini, tidak terdapat penggambaran 
bentuk surya majapahit. Pada bagian tengah tersebut, diisi dengan penggambaran bentuk bulan sabit.

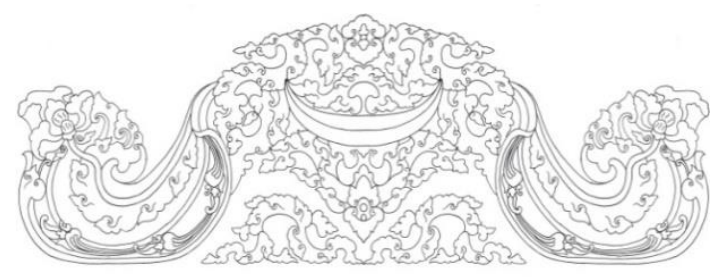

Gambar 18. Motif Sulur

(Sumber: Dokumen Penulis, 2019)

e. Penutup Sisi Belakang

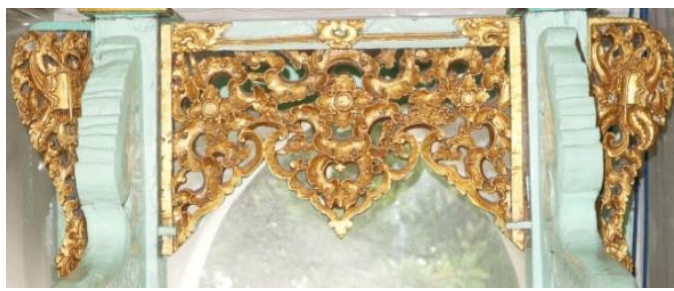

Gambar 19. Penutup Sisi Belakang Mimbar (Sumber: Dokumen Penulis, 2019)

Pada sisi belakang mimbar terdapat ragam hias bermotif sulur. Motif tersebut diletakkan di bagian dalam maupun bagian luar dari sisi belakang mimbar. Motif sulur di bagian dalam terbagi menjadi dua kategori. Pertama, yang berada di bagian bawah. Penggambaran motif sulur di bagian ini membentuk sebuah bidang menyerupai hiasan antefix yang biasa terdapat di candi, akan tetapi disusun secara terbalik. Bagian tengah motif sulur ini dihiasi tiga bunga yang disusun secara horisontal. Ragam hias bermotif sulur tersebut diukir menggunakan teknik ukir tembus atau krawangan.

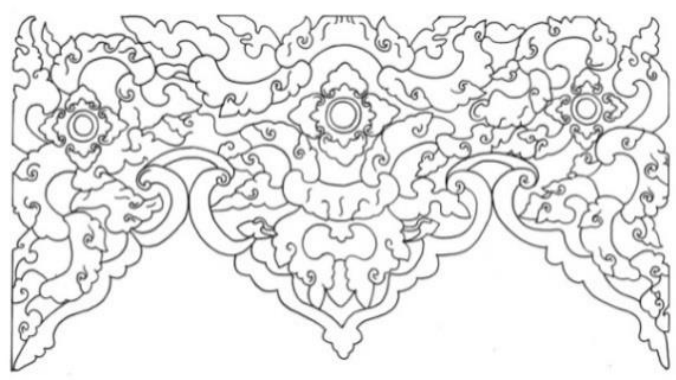

Gambar 20. Motif Sulur (Sumber: Dokumen Penulis, 2019)
Sedangkan yang kedua, adalah motif sulur yang berada di bagian atas. Motif sulur ini diletakkan pada kedua sudut sisi kanan dan kiri dan satu berada di bagian tengah, dari sebuah bidang berbentuk persegi panjang. Di antara ketiga suluran tersebut (dua di setiap sudut, satu di bagian tengah), dihubungkan dengan sebuah bidang berbentuk garis memanjang secara horisontal.

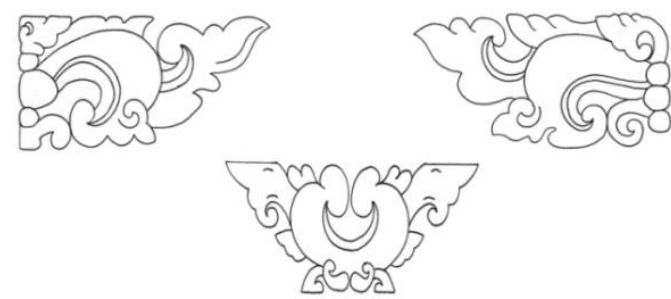

Gambar 21. Motif Sulur

(Sumber: Dokumen Penulis, 2019)

Pada penutup sisi belakang bagian luar terdapat dua bentuk penggambaran ragam hias bermotif sulur. Motif sulur ini hampir mengisi seluruh bidang yang berbentuk menyerupai daun telinga. Pada bagian atas motif sulur, terdapat penggambaran pataka majapahit berupa bendera yang dikelilingi oleh sinar surya majapahit. Penggambaran pataka majapahit pada masing-masing suluran tersebut, disusun saling berhadapan. Sedangkan pada pangkal kedua suluran terdapat hiasan berupa bunga yang sedang mekar dan disusun terbalik, menghadap ke bawah. Kedua motif sulur ini diukir menggunakan teknik ukir tembus atau krawangan.

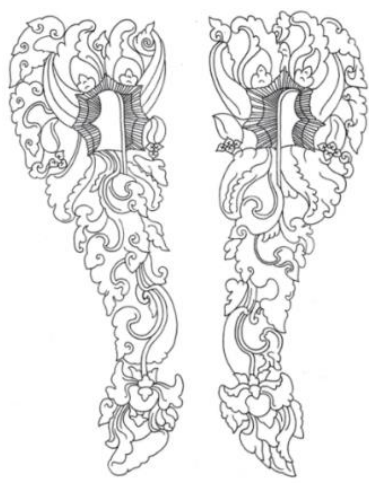

Gambar 22. Motif Sulur (Sumber: Dokumen Penulis, 2019) 
Karakteristik Ragam Hias Mimbar Sunan Prapen

Bentuk ragam hias di mimbar Sunan Prapen memperlihatkan kelanjutan dari gaya seni pra Islam. Gaya seni hias semacam ini dapat ditemukan pada bangunan suci agama Hindu-Budha. Meski demikian, karakteristik seni Islam dapat ditemukan pada ragam hias pada mimbar Sunan Prapen, seperti adanya penggambaran bulan sabit hingga penggambaran makhluk hidup dengan cara distilasi yang terlihat pada ragam hias kala. Ragam hias hiranyagarba juga merupakan ragam hias pra Islam. Dalam ragam hias tersebut terdapat penggambaran gunung hingga pohon hayat yang merupakan salah satu wujud atau simbol suci dalam kepercayaan pra Islam. Keberadaan ragam hias di mimbar Sunan Prapen memperlihatkan bahwa pada masa tersebut Kerajaan Giri Kedaton di bawah kepemimpinan Sunan Prapen tidak melupakan kebudayaan pra Islam, asalkan tidak bertentangan dengan agama Islam. Penghormatan kepada kebudayaan pra Islam, khususnya Kebudayaan Majapahit, misalnya terlihat pada penggunaan Surya Majapahit sebagai hiasan bangunan mimbar. Selain itu, ragam hias sulur yang dipakai di mimbar Sunan Prapen merupakan gaya sulur periode Majapahit.

\section{KESIMPULAN}

Berdasarkan hasil penelitian mengenai kajian bentuk ragam hias pada mimbar Sunan Prapen, dapat ditarik kesimpulan bahwa ragam hias di mimbar Sunan Prapen mendapatkan pengaruh dari gaya seni hias pra Islam. Ragam hias di mimbar Sunan Prapen meneruskan gaya ragam pra Islam, khususnya gaya Majapahit, akan tetapi dengan beberapa pengembangan. Ragam hias di mimbar Sunan Prapen lebih banyak memakai motif-motif dari tumbuh-tumbuhan dan alam. Motif-motif yang berasal dari penggambaran tumbuhtumbuhan antara lain, motif lung-lungan, sulur, dan padma. Sedangkan motif-motif yang berasal dari penggambaran alam seperti motif sorotan dan hiranyagarba. Khusus untuk ragam hias makhluk hidup, dilakukan pengubahan dengan menyamarkannya dengan cara di stilasi yang terlihat pada penggambaran motif kala. Pengubahan bentuk dengan cara stilasi dilakukan untuk menghindari penggambaran makhluk hidup secara realistis. Menginggat penggambaran makhluk hidup secara realistis sangat dilarang dalam agama Islam.

\section{UCAPAN TERIMA KASIH}

Penulis sampaikan terima kasih sebesar-besarnya kepada Bapak Muhammad Ma'arif selaku koordinator departemen hubungan masyarakat dan ketenagaan Masjid Ainul Yaqin Sunan Giri. Terimakasih juga saya sampaikan kepada bapak-bapak pengurus Yayasan Masjid Besar Ainul Yaqin Sunan Giri (YAMAYSURI) yang telah membantu terselesaikanya penelitian ini.

\section{DAFTAR PUSTAKA}

Alamsyah, S. (2010). Nilai Budaya Arsitektur Masjid Sang Cipta Rasa Cirebon Provinsi Jawa Barat. Patanjala, 2(2), 172-190.

Ambary, H. M. (1998). Menemukan Peradaban, Jejak Arkeologis, dan Historis Islam Indonesia. Jakarta: Logos Wacana Ilmu.

Anggarini, S. (2009). Ragam Hias Masjid Dalam Kajian Estetika. Dimensi, 6(2), 207-226.

Djelantik, A. A. M. (2004). Estetika Sebuah Pengantar. Bandung: Masyarakat Seni Pertunjukan Indonesia.

Dorno, J. (2014). Bentuk dan Makna Ornamen Ukir pada Interior Masjid Gedhe Yogyakarta. Universitas Negeri Yogyakarta.

Pradana, R. W. B. (2019). MASJID AINUL YAQIN SUNAN GIRI: Tinjauan Seni Bangunan, Ragam Hias, dan Makna Simbolik. Universitas Negeri Surabaya.

Pradana, R. W. B. (2020). Bentuk dan Makna Simbolik Ragam Hias pada Masjid Sunan Giri. RUANG: Jurnal Lingkungan Binaan (SPACE: Journal of the Built Environment), 7(1). https://doi.org/https://doi.org/10.24843/J RS.2020.v07.i01.p07

Rahym, A. (1983). Masjid Dalam Karya Arsitektur Nasional Indonesia. Bandung: Angkasa. 
Sasti, T. H. (2014). Mihrab dan Mimbar

Masjid Jawa Tengah Abad 16-19 dalam

Kajian Ikonografi. Institut Seni

Indonesia Yogyakarta.

Tjahjono, R. \& J. T. (2004). Tipologi

Konstruksi Tradisional pada Cungkup

Makam Prapen. Ruas, 2(1), 16-25. 